Marquette University

e-Publications@Marquette

$12-2020$

\title{
Quantitative Assessment of Root Development after Regenerative Endodontic Therapy: A Systematic Review and Meta-Analysis
}

Teng Kai Ong

Marquette University

Ghee Seong Lim

University of Malaya

Maharaj Singh

Marquette University, maharaj.singh@marquette.edu

Alissa Fial

Marquette University, alissa.fial@marquette.edu

Follow this and additional works at: https://epublications.marquette.edu/lib_fac

\section{Recommended Citation}

Ong, Teng Kai; Lim, Ghee Seong; Singh, Maharaj; and Fial, Alissa, "Quantitative Assessment of Root Development after Regenerative Endodontic Therapy: A Systematic Review and Meta-Analysis" (2020). Library Faculty Research and Publications. 112.

https://epublications.marquette.edu/lib_fac/112 
Marquette University

e-Publications@Marquette

\section{Raynor Memorial Libraries Faculty Research and Publications/Raynor Memorial Libraries}

This paper is NOT THE PUBLISHED VERSION.

Access the published version via the link in the citation below.

Journal of Endodontics, Vol. 46, No. 12 (December 2020): 1856-1866.e2. DOI. This article is (C) Elsevier and permission has been granted for this version to appear in e-Publications@Marquette. Elsevier does not grant permission for this article to be further copied/distributed or hosted elsewhere without the express permission from Elsevier.

\section{Quantitative Assessment of Root Development after Regenerative Endodontic Therapy: A Systematic Review and Meta- Analysis}

\section{Teng Kai Ong}

Department of Surgical Sciences, Division of Endodontics, Marquette University School of Dentistry, Milwaukee, Wisconsin

Ghee Seong Lim

Department of Restorative Dentistry, Faculty of Dentistry, University of Malaya, Kuala Lumpur, Malaysia

Maharaj Singh

Biostatistics-Research and Graduate Studies, Marquette University School of Dentistry, Milwaukee, Wisconsin

Alissa V. Fial

Marquette University Raynor Memorial Libraries, Milwaukee, Wisconsin 


\begin{abstract}
Introduction

The purposes of this review were to appraise the level of evidence of the existing regenerative endodontic therapy (RET) publications, perform a meta-analysis on the survival and healing rates of necrotic immature permanent teeth treated with RET, and run a meta-analysis on the quantitative assessment of the root development of those teeth.
\end{abstract}

\title{
Methods
}

Electronic searches were performed in Web of Science, PubMed, CINAHL (Cumulative Index to Nursing and Allied Health Literature), and Cochrane Library databases. Two authors independently screened the titles and abstracts for eligibility. The analyses were performed on the clinical outcomes (ie, survival, healing, and root development) of the procedure.

\section{Results}

Eleven articles were included in the qualitative and quantitative syntheses. Three studies were randomized controlled trials, 6 were prospective cohort studies, and 2 were retrospective cohort studies. The pooled survival and healing rates were $97.3 \%$ and $93.0 \%$, respectively. The pooled rates of root lengthening, root thickening, and apical closure were $77.3 \%, 90.6 \%$, and $79.1 \%$, respectively. However, if $20 \%$ radiographic changes were used as a cutoff point, there were only $16.1 \%$ root lengthening and $39.8 \%$ root thickening.

\section{Conclusions}

Within the limitations of the present study, it can be concluded that RET yielded high survival and healing rates with a good root development rate. However, clinical meaningful root development after RET was unpredictable.

\section{Key Words}

Meta-analysis, pulp revascularization, regenerative endodontic therapy, root development, systematic review

\section{Significance}

Regenerative endodontic therapy on necrotic immature permanent teeth was shown to have high survival and healing rates with a good root development rate. However, the existing literature failed to show predictable clinical meaningful root development after regenerative endodontic therapy.

In the health care field, it is crucial for clinicians to set an achievable treatment goal or goals when a treatment plan is proposed to patients. For instance, the goals of endodontic treatment are to treat and to prevent apical periodontitis ${ }^{1}$. Therefore, in the event of healing or absence of apical periodontitis, the treatment is considered successful ${ }^{2,3}$.

However, the management of necrotic mature and immature teeth could be different. The immature tooth often exhibits a wide open apex with no apical stop and thus complicates the root filling. Also, the immature tooth could present with a short root with a compromised crown-to-root ratio at times. 
On top of that, the root dentin of an immature tooth could be rather thin; this is especially concerning at the cervical region because this region is predisposed to catastrophic horizontal root fracture ${ }^{4}$. Apexification using mineral trioxide aggregate as an apical plug (MAP) is 1 of the treatment options in treating necrotic immature teeth that showed high survival and success rates ${ }^{5}$. Nonetheless, MAP in an immature tooth would not encourage the thickening and lengthening of the root, and, certainly, the tooth would remain nonvital. With the advent of regenerative endodontic therapy (RET), this treatment approach could potentially address the drawbacks that is presented in MAP. The American Association of Endodontists described root development as a desirable but nonessential secondary goal of $\mathrm{RET}^{6}$. Therefore, it would be interesting to know the predictability of this desirable goal after RET.

In the past decade, RET in necrotic immature teeth has received much attention, and many articles related to RET have been published ${ }^{7}$. However, there is a lack of standardization of the treatment protocol between studies; therefore, it is hard to make a direct comparison of the treatment outcome from those studies ${ }^{8}$. Additionally, many studies adopted different outcome assessments, with distinct parameters for the success of RET. These problems could easily translate into a false presentation of the data on RET, thus confusing clinicians.

Three previously published systematic reviews assessed the outcome of $\operatorname{RET}^{5,9,10}$. These systematic reviews included both qualitative and quantitative measurements of continued root development after $\mathrm{RET}^{5,9,10}$. However, there could be an interpretation bias if qualitative or visual assessment is used to determine root development. Tong et $\mathrm{al}^{10}$ included only the quantitative measurement of root development after RET in a meta-analysis. However, they only performed the meta-analysis on the studies comparing the outcome with similar exposure and thus omitted many other studies with valuable findings. Therefore, the purposes of this review were as follows:

1. Critically appraise the quality of evidence of the existing RET publications

2. Perform a meta-analysis of the survival and healing rates of necrotic immature permanent teeth treated with RET

3. Run a meta-analysis on the quantitative assessment of the root development of necrotic immature permanent teeth treated with RET

\section{Methods}

\section{Inclusion Criteria}

In the present study, any procedure that attempted to revascularize or regenerate a necrotic immature permanent human tooth with the intention to induce root development was included as RET regardless of the methods of disinfection and the types of scaffolds used. Root development including root lengthening, root thickening, and/or apical closure was discussed separately and measured quantitatively.

\section{Exclusion Criteria}

The criteria for excluding studies were as follows:

1. Nonhuman studies

2. Abstract and title do not meet the inclusion criteria 


\section{Review articles}

4. Descriptive case report or case series

5. Non-English studies

6. Study included primary teeth or mature permanent teeth

7. Full article not found

The clinical exclusion criteria were the following:

1. Pulpal diagnosis other than pulp necrosis

2. Follow-up less than 12 months

3. An orifice barrier other than calcium silicate-based material was used

4. Visual comparison or assessment on root development

5. Root development for each sample was not mentioned or not quantifiable

6. Root lengthening, thickening, and apical closure were discussed or measured as a whole in root development

\section{Search Strategy and Outcome Measures}

With the assistance of a medical librarian, literature searches were conducted in the following electronic databases: PubMed/MEDLINE, CINAHL (Cumulative Index to Nursing and Allied Health Literature), Cochrane Clinical Trials, and Web of Science. The parameters included an initial focus on regenerative endodontics in teeth, both immature and permanent, and pulp necrosis. Special attention was focused on determining the terminology that concentrated on procedures and therapies for regenerative endodontics. Additionally, terminology specific to necrosis, apical abscess, and pathology were included. The initial search was conducted in December 2019. For a complete list of the literature search strategies, see Appendix 1.

The results were limited to the English language only. The publication date range was selected as 1990-2019. There was no limit on the type of publication. The search strategy was first established in PubMed/MEDLINE using a combination of Medical Subject Headings (MeSH) (database controlled vocabulary) and key words. The MeSH headings were searched along with the key words. Specific MeSH terminology included regenerative endodontics, periapical abscess, periapical periodontitis, and dental pulp necrosis. From there, the other database search strategies were developed, and searches were conducted. With each database search, the database's controlled vocabulary was searched in combination with key words. The search yielded 3088 publications, with 2608 reviewed after duplicates were removed. Eleven publications were included in this meta-analysis. The Preferred Reporting Items for Systematic Reviews and Meta-Analyses flowchart summarizing the systematic review process is provided in Figure 1. 


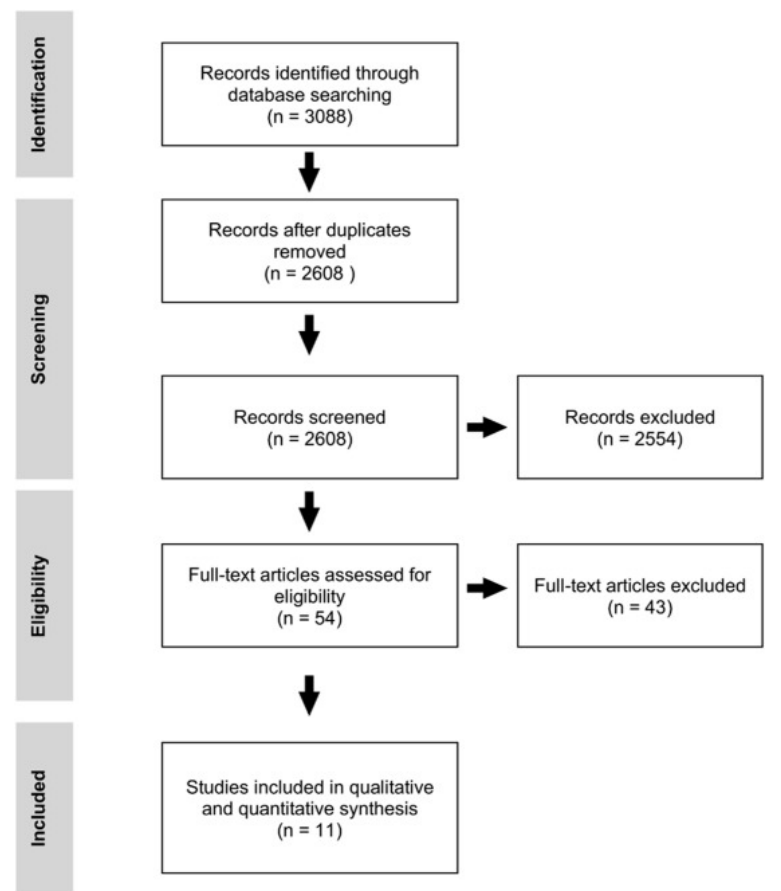

Figure 1. The Preferred Reporting Items for Systematic Reviews and Meta-Analyses flow diagram.

\section{Quality Analysis and Level of Evidence}

All of the articles were assessed by 2 reviewers (T.K.O. and G.S.L.) independently. The NewcastleOttawa Scale was used to assess the quality of the observational studies (cohort studies), and the Cochrane risk of bias tool was used to assess the quality of randomized controlled trial and uncontrolled prospective trial studies. The Scottish Intercollegiate Guidelines Network Grading System was used to grade the level of evidence (LOE) for the articles included in this study. In the event of a disagreement, consensus was reached by discussion.

\section{Clinical Outcomes}

Survival was defined as the tooth being retained after the treatment at follow-up. Healing was defined as the absence of clinical symptoms with resolution of the periapical radiolucency. Root lengthening was defined as the increment of the root length. Root thickening was defined as the increment of root thickness. Apical narrowing/closure was defined as narrowing of the apical diameter of the root. The radiographic root area (RRA) was defined as the changes on the total root area. The $20 \%$ percent cutoff point on radiographic changes was defined when the measurement of root changes (root lengthening, root thickening, apical narrowing/closure, and RRA) showed more than a $20 \%$ positive value. Intracanal calcification was defined as any form of calcification detected in the root canal including calcific barrier formation, partial pulpal obliteration, and total pulpal obliteration.

\section{Statistical Analysis}

All percentages were converted into proportions, and statistical analysis was performed using proportions and the total sample in the studies. The effect size of the proportions for all the studies that had complete data was computed. Heterogeneity among studies was computed as $I^{2}$. For all computations, an alpha level of 0.05 was used. In the present study, both the fixed and random effects were computed, but only the random effect was adopted for the interpretation of results. The 
statistical analyses and computations were performed using Comprehensive Meta-Analysis Version 3.3.070 (Biostat, Englewood, NJ).

\section{Results}

\section{Study Design}

In all, 11 studies were included in this study $11,12,13,14,15,16,17,18,19,20,21$ (Table 1). Of these 11 studies, 3 were randomized controlled trials ${ }^{12,15,20}$, and the rest were observational studies with 6 prospective cohort studies $^{11,13,14,18,19,21}$ and 2 retrospective cohort studies ${ }^{16,17}$. 
Table 1. The Studies Included in the Systematic Review and Meta-analysis

\begin{tabular}{|c|c|c|c|c|c|c|c|c|c|c|c|c|c|c|}
\hline First author & Year & $\begin{array}{l}\text { Sample } \\
\text { size }\end{array}$ & Study design & $\begin{array}{l}\text { Age } \\
\text { (y) }\end{array}$ & $\begin{array}{l}\text { Male:female } \\
\text { ratio }\end{array}$ & Tooth & $\begin{array}{l}\text { Follow- } \\
\text { up } \\
\text { (mo) }\end{array}$ & Etiology & $\begin{array}{l}\mathrm{NaOCl} \% \\
\text { (concentration) }\end{array}$ & Medication & EDTA & Scaffold & Barrier & $\begin{array}{l}\text { Permanent } \\
\text { restoration }\end{array}$ \\
\hline Kahler ${ }^{11}$ & 2014 & 9 & $\begin{array}{l}\text { Prospective } \\
\text { cohort study }\end{array}$ & $8-12$ & $2: 7$ & $A / P$ & $18-36$ & $\begin{array}{l}\text { Trauma, anomalies, } \\
\text { unknown }\end{array}$ & 1 & $\begin{array}{l}\text { Metronidazole, } \\
\text { ciprofloxacin, amoxicillin }\end{array}$ & No & Blood clot & MTA & $\begin{array}{l}\text { Glass } \\
\text { ionomer } \\
\text { restoration }\end{array}$ \\
\hline Bezgin $^{12}$ & 2015 & 20 & $\mathrm{RCT}$ & $7-12$ & $11: 9$ & $A / P$ & 18 & Trauma, caries & 2.5 & $\begin{array}{l}\text { Metronidazole, } \\
\text { ciprofloxacin, cefaclor }\end{array}$ & Yes & $\begin{array}{l}\text { PRP/blood } \\
\text { clot }\end{array}$ & MTA & $\begin{array}{l}\text { Composite } \\
\text { restoration }\end{array}$ \\
\hline Chan $^{13}$ & 2017 & 28 & $\begin{array}{l}\text { Prospective } \\
\text { cohort study }\end{array}$ & $\begin{array}{l}9.23 \\
\pm \\
2.36\end{array}$ & $12: 10$ & $\mathrm{~A} / \mathrm{P} / \mathrm{M}$ & 30 & $\begin{array}{l}\text { Trauma, anomalies, } \\
\text { caries }\end{array}$ & 5.25 & $\begin{array}{l}\text { Metronidazole, } \\
\text { ciprofloxacin, cefaclor }\end{array}$ & No & $\begin{array}{l}\text { Blood clot } \\
\text { (collaplug) }\end{array}$ & MTA & $\begin{array}{l}\text { Composite } \\
\text { restoration }\end{array}$ \\
\hline $\mathrm{Li}^{14}$ & 2017 & 20 & $\begin{array}{l}\text { Prospective } \\
\text { cohort study }\end{array}$ & $\begin{array}{l}10.6 \\
\pm \\
0.995 \\
\end{array}$ & 9:11 & $P$ & 12 & Anomalies & 2.5 & Calcium hydroxide & No & Blood clot & MTA & $\begin{array}{l}\text { Composite } \\
\text { restoration }\end{array}$ \\
\hline $\operatorname{Lin}^{15}$ & 2017 & 69 & RCT & $8-16$ & NS & $A / P$ & 12 & Trauma, anomalies & 1.5 & $\begin{array}{l}\text { Metronidazole, } \\
\text { ciprofloxacin, } \\
\text { clindamycin }\end{array}$ & Yes & Blood clot & MTA & $\begin{array}{l}\text { Composite } \\
\text { restoration }\end{array}$ \\
\hline Peng $^{16}$ & 2017 & 28 & $\begin{array}{l}\text { Retrospective } \\
\text { cohort study }\end{array}$ & $\begin{array}{l}10.7 \\
\pm 2.2\end{array}$ & $15: 13$ & $A / P$ & $13-63$ & $\begin{array}{l}\text { Trauma, anomalies, } \\
\text { caries }\end{array}$ & 5.25 & $\begin{array}{l}\text { Ciprofloxacin, } \\
\text { metronidazole, } \\
\text { minocycline }\end{array}$ & No & Blood clot & MTA & $\begin{array}{l}\text { Composite } \\
\text { restoration }\end{array}$ \\
\hline Silujjai ${ }^{17}$ & 2017 & 17 & $\begin{array}{l}\text { Retrospective } \\
\text { cohort study }\end{array}$ & $8-46$ & $7: 10$ & $A / P / M$ & $12-93$ & $\begin{array}{l}\text { Trauma, anomalies, } \\
\text { caries }\end{array}$ & $1.5-2.5$ & $\begin{array}{l}\text { Ciprofloxacin, } \\
\text { metronidazole, } \\
\text { minocycline }\end{array}$ & Yes & Blood clot & MTA & $\begin{array}{l}\text { Composite } \\
\text { restoration }\end{array}$ \\
\hline Nazzal $^{18}$ & 2018 & 12 & $\begin{array}{l}\text { Prospective } \\
\text { cohort study }\end{array}$ & $7-10$ & $10: 2$ & $A$ & $18-27$ & Trauma & 0.5 & $\begin{array}{l}\text { Metronidazole, } \\
\text { ciprofloxacin }\end{array}$ & Yes & Blood clot & \begin{tabular}{|l|} 
Portland \\
cement
\end{tabular} & $\begin{array}{l}\text { Composite } \\
\text { restoration }\end{array}$ \\
\hline EzEldeen $^{19}$ & 2015 & 5 & $\begin{array}{l}\text { Prospective } \\
\text { cohort study }\end{array}$ & $8-15$ & $0: 5$ & $A / P$ & $\begin{array}{l}19.4 \pm \\
5.4\end{array}$ & $\begin{array}{l}\text { Trauma, anomalies, } \\
\text { autotransplantation }\end{array}$ & 2.5 & $\begin{array}{l}\text { Metronidazole, } \\
\text { ciprofloxacin }\end{array}$ & Yes & Blood clot & MTA & $\begin{array}{l}\text { Composite } \\
\text { restoration }\end{array}$ \\
\hline Shivashankar ${ }^{20}$ & 2017 & 54 & $\mathrm{RCT}$ & $6-28$ & $\begin{array}{l}\text { 32:28 (6 } \\
\text { dropped } \\
\text { out) }\end{array}$ & $A$ & 12 & Trauma, caries & 5.25 & $\begin{array}{l}\text { Ciprofloxacin, } \\
\text { metronidazole, } \\
\text { minocycline }\end{array}$ & No & \begin{tabular}{|l} 
Blood \\
clot/ \\
PRP/PRF
\end{tabular} & MTA & $\begin{array}{l}\text { Not } \\
\text { mentioned }\end{array}$ \\
\hline Saoud $^{21}$ & 2014 & 20 & $\begin{array}{l}\text { Prospective } \\
\text { cohort study }\end{array}$ & $\begin{array}{l}11.3 \\
\pm 1.9\end{array}$ & $14: 6$ & $A$ & 12 & Trauma & 2.5 & $\begin{array}{l}\text { Ciprofloxacin, } \\
\text { metronidazole, } \\
\text { minocycline }\end{array}$ & No & Blood clot & MTA & $\begin{array}{l}\text { Composite } \\
\text { restoration }\end{array}$ \\
\hline
\end{tabular}

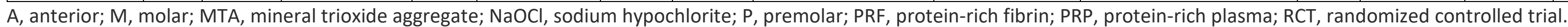


Quality Assessment of Risk of Bias

A high level of bias was evident in 2 randomized controlled trials (LOE $=-1$ ), and a low level of bias was evident in 1 randomized controlled trial (LOE = 1). Also, a high level of bias was found in all uncontrolled prospective trials ( $\mathrm{LOE}=3$ ). Both cohort studies scored 8 of $9(\mathrm{LOE}=2++$ ) and therefore were considered of high quality. Tables 2 and 3 show the quality assessment of the articles and the risk of bias summary, respectively.

Table 2. The Newcastle-Ottawa Scale for Retrospective Cohort Studies

\begin{tabular}{|l|l|l|}
\hline Study & $\begin{array}{l}\text { Peng et al, } \\
\mathbf{2 0 1 7}\end{array}$ & $\begin{array}{l}\text { Silujjai and } \\
\text { Linsuwanont, 2017 }\end{array}$ \\
\hline 1. Selection & & \\
\hline A. Representativeness of the exposed cohort & + & + \\
\hline B. Selection of the nonexposed cohort & & \\
\hline C. Ascertainment of exposure & + & + \\
\hline $\begin{array}{l}\text { D. Demonstration that outcome of interest was not present at } \\
\text { start of study }\end{array}$ & + & + \\
\hline 2. Comparability & & \\
\hline $\begin{array}{l}\text { A. Comparability of cases and controls/cohorts on the basis of } \\
\text { the design or analysis }\end{array}$ & ++ & ++ \\
\hline 3. Outcome & & \\
\hline A. Assessment of outcome & + & + \\
\hline B. Was follow-up long enough for outcomes to occur & + & + \\
\hline C. Adequacy of follow-up of cohorts & + & + \\
\hline Total & $8 / 9$ & $8 / 9$ \\
\hline Sign LOE & $2++$ & $2++$ \\
\hline
\end{tabular}

+ , yes; LOE, level of evidence.

Table 3. The Risk of Bias Summary and Classification of Level of Evidence Outcomes

\begin{tabular}{|l|l|l|l|l|l|l|l|l|l|}
\hline $\begin{array}{l}\text { First } \\
\text { author, } \\
\text { year }\end{array}$ & $\begin{array}{l}\text { Rando } \\
\text { m } \\
\text { sequen } \\
\text { ce } \\
\text { generat } \\
\text { ion }\end{array}$ & $\begin{array}{l}\text { Allocatio } \\
\text { n } \\
\text { conceal } \\
\text { ment }\end{array}$ & $\begin{array}{l}\text { Blinding } \\
\text { of } \\
\text { particip } \\
\text { ants and } \\
\text { personn } \\
\text { el }\end{array}$ & $\begin{array}{l}\text { Blinding } \\
\text { of } \\
\text { outcom } \\
\text { e } \\
\text { assessm } \\
\text { ent }\end{array}$ & $\begin{array}{l}\text { Incompl } \\
\text { ete } \\
\text { outcom } \\
\text { e data }\end{array}$ & $\begin{array}{l}\text { Selecti } \\
\text { ve } \\
\text { report } \\
\text { ing }\end{array}$ & $\begin{array}{l}\text { Other } \\
\text { poten } \\
\text { tial } \\
\text { threat } \\
\text { sto } \\
\text { validit } \\
\text { y }\end{array}$ & $\begin{array}{l}\text { Othe } \\
\text { r } \\
\text { sourc } \\
\text { es of } \\
\text { bias }\end{array}$ & $\begin{array}{l}\text { Sign } \\
\text { gradi } \\
\text { ng }\end{array}$ \\
\hline $\begin{array}{l}\text { Kahler, } 201 \\
4^{11}\end{array}$ & NA & NA & NA & - & + & + & - & - & 3 \\
\hline $\begin{array}{l}\text { Bezgin, } 201 \\
5^{12}\end{array}$ & - & - & - & + & + & + & + & - & -1 \\
\hline $\begin{array}{l}\text { Chan, } 2017^{1} \\
3\end{array}$ & NA & NA & NA & - & + & + & + & + & 3 \\
\hline Li, 2017 & NA & NA & NA & - & + & + & + & + & 3 \\
\hline Lin, $2017^{15}$ & + & + & - & - & + & + & + & $?$ & -1 \\
\hline $\begin{array}{l}\text { Nazzal, } 201 \\
8^{18}\end{array}$ & NA & NA & NA & - & + & + & + & $?$ & 3 \\
\hline
\end{tabular}




\begin{tabular}{|l|l|l|l|l|l|l|l|l|l|}
\hline $\begin{array}{l}\text { EzEldeen, } 2 \\
015^{19}\end{array}$ & NA & NA & NA & - & + & + & + & - & 3 \\
\hline $\begin{array}{l}\text { Shivashank } \\
\text { ar, } 2017^{20}\end{array}$ & + & + & + & + & + & + & + & $?$ & 1 \\
\hline $\begin{array}{l}\text { Saoud, } 201 \\
4^{21}\end{array}$ & NA & NA & NA & $?$ & + & + & + & $?$ & 3 \\
\hline
\end{tabular}

-, high risk; ?, unclear risk; +, low risk; NA, not applicable.

\section{Analysis of Outcome Measures}

Table 4 summarizes the outcome of the analytic studies, whereas Table 5 summarizes the outcome of the included studies differentiated by their etiologies.

Table 4. The Outcome of Analytic Studies

\begin{tabular}{|c|c|c|c|c|c|c|c|c|c|c|c|c|}
\hline $\begin{array}{l}\text { First } \\
\text { author, } \\
\text { year }\end{array}$ & $\begin{array}{l}\text { Sam } \\
\text { ple } \\
\text { size }\end{array}$ & $\begin{array}{l}\text { Survi } \\
\text { val }\end{array}$ & $\begin{array}{l}\text { Heal } \\
\text { ing }\end{array}$ & $\begin{array}{l}\text { Root } \\
\text { length } \\
\text { ening }\end{array}$ & $\begin{array}{l}\text { Root } \\
\text { thicke } \\
\text { ning }\end{array}$ & $\begin{array}{l}\text { Apical } \\
\text { narro } \\
\text { wing }\end{array}$ & $\begin{array}{l}\text { RR } \\
\text { A }\end{array}$ & $\begin{array}{l}\text { Root } \\
\text { length } \\
\text { ening } \\
\text { (>20\%) }\end{array}$ & $\begin{array}{l}\text { Root } \\
\text { thicke } \\
\text { ning } \\
\text { (>20\% } \\
\text { ) }\end{array}$ & $\begin{array}{l}\text { Apical } \\
\text { narro } \\
\text { wing } \\
\text { (>20\% } \\
\text { ) }\end{array}$ & $\begin{array}{l}\text { RRA } \\
(>2 \\
0 \%)\end{array}$ & $\begin{array}{l}\text { Calcific } \\
\text { barrier } \\
\text { or intra } \\
\text { canal } \\
\text { calcifica } \\
\text { tion }\end{array}$ \\
\hline $\begin{array}{l}\text { Kahler, } \\
2014^{11} *\end{array}$ & 9 & - & - & 44.4 & 88.9 & - & - & 11.1 & 55.6 & - & - & - \\
\hline $\begin{array}{l}\text { Kahler, } \\
2014^{11}\end{array}$ & 16 & 100 & 90.3 & - & - & 66.6 & - & - & - & - & - & - \\
\hline $\begin{array}{l}\text { Bezgin, } \\
2015^{12}\end{array}$ & 20 & 100 & 95 & - & - & 65 & 90 & - & - & - & 20 & 40 \\
\hline $\begin{array}{l}\text { Chan, } \\
2017^{13}\end{array}$ & 28 & 96.4 & 92.9 & 91.7 & - & 92.9 & $\begin{array}{l}81 \\
.8\end{array}$ & 0 & 0 & 82 & 0 & - \\
\hline $\begin{array}{l}\mathrm{Li}, \\
2017^{14}\end{array}$ & 20 & 100 & 100 & 100 & - & 100 & $\begin{array}{l}10 \\
0\end{array}$ & 55 & - & 100 & 100 & - \\
\hline $\begin{array}{l}\text { Lin, } \\
2017^{15}\end{array}$ & 69 & 100 & 100 & 81.2 & 82.6 & 65.2 & - & - & - & - & - & 37.7 \\
\hline $\begin{array}{l}\text { Peng, } \\
2017^{16}\end{array}$ & 28 & 96.4 & 92.9 & - & - & - & - & - & - & - & - & 29 \\
\hline $\begin{array}{l}\text { Peng, } \\
2017^{16} *\end{array}$ & 24 & - & - & 79.2 & 91.7 & - & - & 29.2 & 58.3 & - & - & - \\
\hline $\begin{array}{l}\text { Silujjai, } \\
2017^{17}\end{array}$ & 17 & 100 & 76.5 & 58.8 & 70.6 & - & - & 11.8 & 29.4 & - & - & 23.5 \\
\hline $\begin{array}{l}\text { Nazzal, } \\
2018^{18}\end{array}$ & 12 & 100 & 100 & 58.3 & 50 & 75 & - & - & - & - & - & - \\
\hline $\begin{array}{l}\text { EzEldee } \\
n, \\
2015^{19}\end{array}$ & 5 & 100 & 100 & 100 & 100 & 100 & - & - & - & 100 & - & 100 \\
\hline $\begin{array}{l}\text { Shivasha } \\
\text { nkar, } \\
2017^{20}\end{array}$ & 54 & 100 & 96.3 & 74.1 & 81.5 & - & - & - & - & - & - & 5.6 \\
\hline $\begin{array}{l}\text { Saoud, } \\
2014^{21}\end{array}$ & 20 & 100 & 100 & 95 & 90 & 100 & - & 0 & 45 & 100 & - & 25 \\
\hline
\end{tabular}

- , no data available; RRA, radiographic root area.

*Only part of the samples was analyzed as incomplete data provided in the study; - indicates no data available. 

Table 5. The Outcomes of Studies Differentiated by Etiologies

\begin{tabular}{|c|c|c|c|c|c|c|c|c|c|c|c|c|c|}
\hline Etiology & $\begin{array}{l}\text { First author, } \\
\text { year }\end{array}$ & $n$ & Survival & Healing & $\begin{array}{l}\text { Root } \\
\text { length } \\
\text { ening }\end{array}$ & $\begin{array}{l}\text { Root } \\
\text { thickening }\end{array}$ & $\begin{array}{l}\text { Apical } \\
\text { narro } \\
\text { wing }\end{array}$ & RRA & $\begin{array}{l}\text { Root } \\
\text { lengthe } \\
\text { ning } \\
(>20 \%)\end{array}$ & $\begin{array}{l}\text { Root } \\
\text { thickeni } \\
\text { ng } \\
(>20 \%)\end{array}$ & $\begin{array}{l}\text { Apical } \\
\text { narrow } \\
\text { ing } \\
\text { (>20\%) }\end{array}$ & $\begin{array}{l}\text { RRA } \\
\text { (>20\% } \\
\text { ) }\end{array}$ & $\begin{array}{l}\text { Calcific } \\
\text { barrier or } \\
\text { intracanal } \\
\text { calcificatio } \\
\mathbf{n}\end{array}$ \\
\hline \multirow[t]{7}{*}{ Trauma } & Kahler, $2014^{11}$ & 5 & 100 & - & 60 & 80 & - & - & 20 & 20 & - & - & - \\
\hline & Bezgin, $2015^{12}$ & 14 & 100 & 92.9 & - & - & 65 & 85 & - & - & - & 14.3 & - \\
\hline & Lin, $2017^{15}$ & 21 & 100 & 100 & 42.9 & - & 61.9 & - & - & - & - & - & - \\
\hline & Silujjiai, $2017^{17}$ & 5 & 100 & 80 & 40 & 60 & 一 & 一 & 0 & 0 & 一 & 一 & 0 \\
\hline & Nazzal, $2018^{18}$ & 12 & 100 & 100 & 58.3 & 50 & 75 & - & - & - & - & - & - \\
\hline & $\begin{array}{l}\text { EzEldeen, } \\
2015^{19}\end{array}$ & 1 & 100 & 100 & 100 & 100 & 100 & - & - & - & 100 & - & 100 \\
\hline & Saoud, $2014^{21}$ & 20 & 100 & 100 & 95 & 90 & 100 & - & 0 & 45 & 100 & - & 25 \\
\hline \multirow{5}{*}{$\begin{array}{l}\text { Dental } \\
\text { anomalie } \\
\text { s }\end{array}$} & Kahler, $2014^{11}$ & 2 & 100 & - & 50 & 100 & - & - & 0 & 100 & - & - & - \\
\hline & $\mathrm{Li}, 2017^{14}$ & 20 & 100 & 100 & 100 & - & 100 & 100 & 55 & - & 100 & 100 & - \\
\hline & Lin, $2017^{15}$ & 48 & 100 & 100 & 97.9 & - & 91.7 & - & - & - & - & - & 一 \\
\hline & Silujjai, $2017^{17}$ & 10 & 100 & 70 & 60 & 80 & - & - & 20 & 40 & - & - & 30 \\
\hline & $\begin{array}{l}\text { EzEldeen, } \\
2015^{19}\end{array}$ & 3 & 100 & 100 & 100 & 100 & 100 & - & - & 100 & - & - & 100 \\
\hline \multirow[t]{2}{*}{ Caries } & Bezgin, $2015^{12}$ & 6 & 100 & 100 & - & - & 100 & 100 & - & - & - & 33.3 & - \\
\hline & Silujjai, $2017^{17}$ & 2 & 100 & 100 & 100 & 50 & - & - & 0 & 50 & - & - & 50 \\
\hline
\end{tabular}

-, no data available; RRA, radiographic root area. 


\section{Follow-up Period}

There was a wide variability in the follow-up period among the studies. The follow-up period ranged from 12-93 months (Table 1).

\section{Survival Rate}

The total sample for 11 studies was 289 . The point estimate for the rate of tooth survival was $97.32 \%$ (95\% confidence interval $[\mathrm{Cl}], 94.34 \%-98.75 \% ; P<.01 ; I^{2}=0$ ) (Fig. $\left.2 A\right)$.

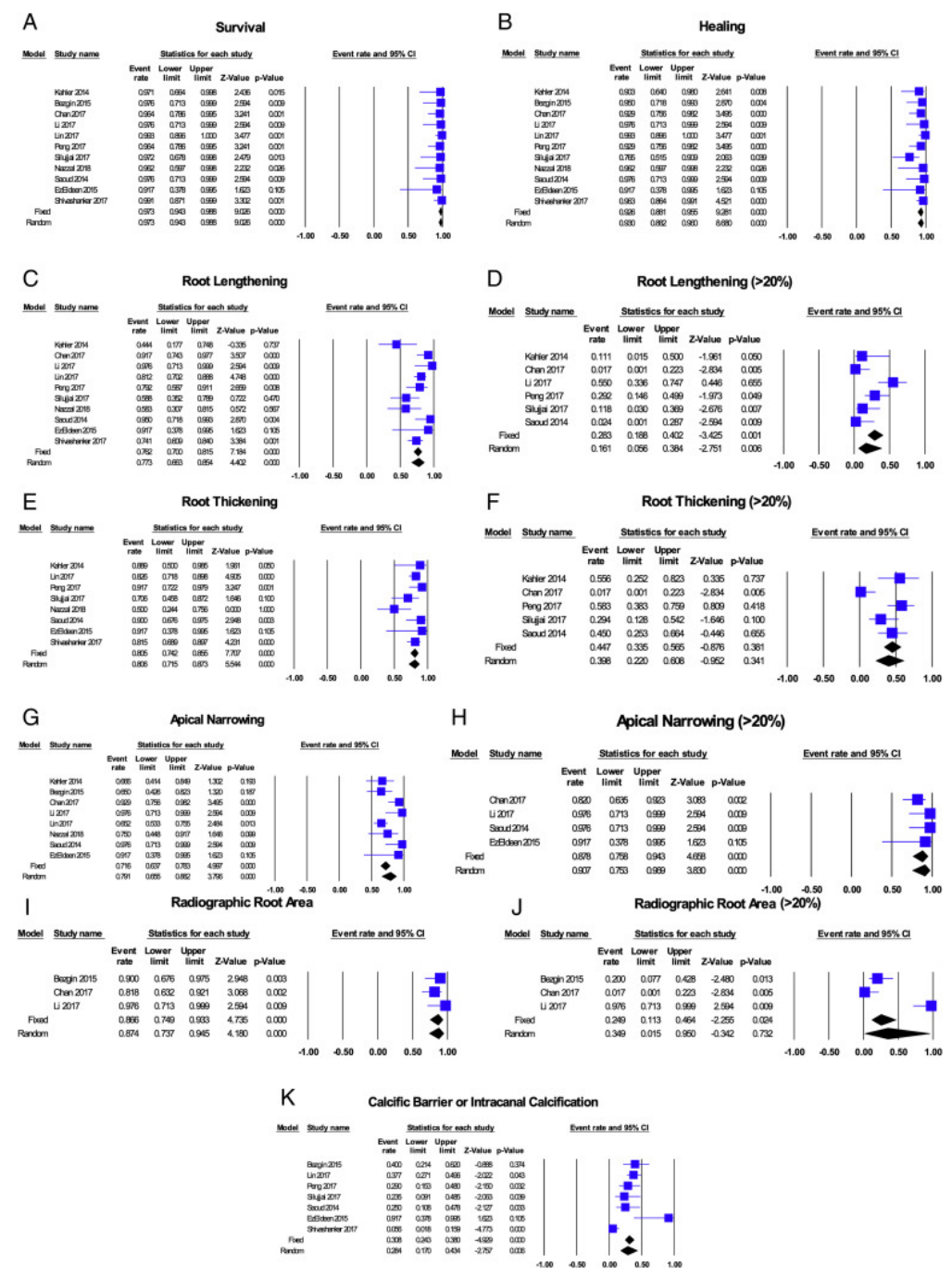

Figure 2. A forest plot for $(A)$ survival rates, $(B)$ healing rates, $(C)$ root lengthening, $(D)$ root lengthening $>20 \%$, $(E)$ root thickening, $(F)$ root thickening $>20 \%,(G)$ apical narrowing, $(H)$ apical narrowing $>20 \%$, $(I)$ RRA, $(J)$ RRA $>20 \%$, and $(K)$ a calcific barrier or intracanal calcification.

\section{Healing Rate}

The healing rate was reported in all of the articles and evaluated through clinical and radiographic means. The total sample was 289 with a healing rate of $93.0 \%\left(95 \% \mathrm{Cl}, 88.16 \%-96.00 \% ; P<.01 ; I^{2}=\right.$ 0) Fig. 2B). 


\section{Root Development}

\section{Root Lengthening}

Root lengthening was reported in 10 of 11 studies, with a total sample of $258 ; 77.3 \%(95 \% \mathrm{Cl}, 66.34 \%-$ 85.41\%; $P<.01 ; I^{2}=55.72$ ) (Fig. 2C) of these samples showed root lengthening. Of these 10 studies, 6 studies (with a total sample of 118) showed the data availability on the $20 \%$ cutoff point of root lengthening. Only $16.1 \%\left(95 \% \mathrm{Cl}, 5.59 \%-38.35 \% ; P<.01 ; I^{2}=72.42\right)$ (Fig. $\left.2 D\right)$ of these samples showed more than $20 \%$ of root lengthening at follow-up.

\section{Root Thickening}

Root thickening was reported in 8 studies, with a total sample of $210 ; 80.6 \%(95 \% \mathrm{Cl}, 71.53 \%-$ 87.31\%; $P<.01 ; I^{2}=36.30$ ) (Fig. $2 E$ ) of these samples showed root thickening. Of these 8 studies, 5 studies (with a total sample of 98 ) showed the data availability on the $20 \%$ cutoff point of root thickening; 39.8\% (95\% Cl, 21.98\%-60.79\%; $\left.P=.34 ; I^{2}=63.43\right)$ (Fig. $\left.2 F\right)$ of these samples showed more than $20 \%$ of root thickening at follow-up.

\section{Apical Narrowing or Apical Closure}

Apical narrowing was reported in 8 studies, with a total sample of $190 ; 79.1 \%(95 \% \mathrm{Cl}, 65.53 \%-$ 88.22\%; $P<.01 ; I^{2}=55.31$ ) (Fig. 2G) of these samples showed apical narrowing. Of these 8 studies, 4 studies (with a total sample of 73 ) showed the data availability of the $20 \%$ cutoff point of apical narrowing; 90.7\% (95\% Cl, 75.26\%-96.91\%; $\left.P<.01 ; I^{2}=23.12\right)$ (Fig. $2 H$ ) of these samples showed more than $20 \%$ of apical narrowing at follow-up.

\section{RRA}

RRA was only reported in 3 studies, with a total sample of $68 ; 87.4 \%(95 \% \mathrm{Cl}, 73.71 \%-94.53 \%$; $P<$ $\left..01 ; I^{2}=17.13\right)($ Fig. 2 I) of these samples showed the increment of RRA. However, only $34.9 \%(95 \% \mathrm{Cl}$, 1.49\%-95.02\%; $P=.73 ; R^{2}=87.36$ ) (Fig. $2 \mathrm{~J}$ ) of the samples showed the RRA increment when $20 \%$ was used as a cutoff point.

\section{Other Radiographic Findings}

Intracanal calcification was reported in 7 of 11 studies, with a total sample of 213 . Only $28.4 \%(95 \% \mathrm{Cl}$, $17.03 \%-43.35 \% ; P<.01 ; I^{2}=69.07$ ) (Fig. $2 K$ ) of these samples showed intracanal calcification.

\section{Discussion}

RET has been shown to present with high survival and success rates in a meta-analysis study ${ }^{5}$. However, the pure healing of apical periodontitis according to how it is defined in the aforementioned study does not necessarily mean the true "success" of RET ${ }^{22}$. Therefore, in the present study, pure resolution of apical periodontitis would be termed healing of RET. The present meta-analysis study showed that the survival and healing rates of RET were $97.3 \%$ and $93 \%$, respectively. This outcome is similar to the aforementioned meta-analysis study, which exhibited a $97.5 \%$ survival rate and a $93.7 \%$ success rate in $\mathrm{RET}^{5}$.

Root development was frequently interpreted as the presence of root thickening, root lengthening, and apical closure ${ }^{5,12,23}$. Nevertheless, apical closure or narrowing is a physiological process of root maturation, and it could even be observed in apexification ${ }^{15}, 24,25,26,27$. Its occurrence relies on the 
viability of the epithelial root sheath and the presence of vital cells (fibroblast and cementoblast) at the apical region ${ }^{28}$. Therefore, its sole presentation without evidence of root thickening and lengthening should not be considered as root development nor seen as a "success" of RET. Even in the event of failed RET, continued apical closure could be demonstrated ${ }^{29}$. Therefore, in the present study, the authors only included studies in which the degrees of root lengthening, root thickening, and apical narrowing after RET were evaluated separately. Apical closure and apical narrowing are the terminologies often used interchangeably even though there are some fundamental differences between the 2. However, the authors were not able to distinguish apical narrowing from apical closure in most of the studies included in this meta-analysis evaluation because the 2 terminologies were used haphazardly. Taking both into consideration, the apical closure or apical narrowing found in this metaanalysis was $79.1 \%$, and this finding is comparable to the meta-analysis study by Tong et $\mathrm{al}^{10}$.

Many published RET studies used qualitative or visual assessment to determine the presence of root development in the past30, 31, 32, 33, 34, which may engender interpretation bias. Therefore, in this meta-analysis, only the studies with quantitative measurement of root development performed were included. Besides, the different angulation in positioning of the X-ray beam could lead to radiographic image distortions, giving rise to the wrong interpretation of the result. A few studies showed some negative values in root development after RET, and this indicated the inconsistency in radiographic positioning11,12,16,21. Likewise, it is arguable that some positive values in root development after RET could be caused by an error in radiographic positioning. Therefore, it is vital to acknowledge that without standardization in assessing and evaluating root development, bias in the studies cannot be repudiated. However, it is understandable that standardization of radiography is sometimes difficult, especially with young patients. The use of quantitative assessment of root lengthening and thickening should eliminate evaluation bias as much as possible. The present meta-analysis showed more than $75 \%$ of root lengthening $(77.3 \%)$ and root thickening $(80.6 \%)$ after RET. Nevertheless, there is a drawback of using quantitative assessment of root length or root thickness; any trivial increment of the root length or the root thickness will be reported as positive root development. Even though this has not been scientifically proven, it would be consequential to recognize the practicability of minute radiographic changes and their clinical significance. With this presumption, it would be ambivalent if RET should be advocated or would be beneficial to patients, especially when the other available treatment option such as apexification could provide a similar clinical outcome ${ }^{5}$. Therefore, the root development after RET presented in the published studies without considering the degree of increment could overestimate the outcome and the "benefits" of RET.

Alobaid et al ${ }^{34}$ suggested that $20 \%$ of the radiographic increment of root length and root width is of clinical significance. This $20 \%$ threshold is an arbitrary figure, and it has not been tested scientifically. However, the assumption of a $20 \%$ threshold of clinical significance could be used to avoid overestimation of the "benefits" of RET, either due to trivial root maturation and/or false interpretation because of the error in radiographic positioning. With this cutoff point, the present meta-analysis showed there were $16.1 \%, 39.8 \%$, and $90.7 \%$ of root lengthening, root thickening, and apical closure/narrowing after RET, respectively. This showed that clinically significant root development (root lengthening or thickening) was not predictable. Studies have shown that age, apical diameter, stage of root development, and follow-up time could influence the degree of root development after RET 13,14,21,35. Also, clinical execution of RET would affect the extent of root 
development as well. For instance, if the coronal barrier placed over the blood clot is pushed deep into the canal, the amount of root development would be restricted by the canal space availability for regeneration. Thus, all the aforementioned factors should be taken into consideration in RET to demonstrate predictable and clinically significant root development.

RRA was suggested by Flake et $\mathrm{al}^{36}$ to assess the overall root development. Even though there were only 3 studies using this assessment, RRA assessment was included in this meta-analysis because a study showed that the RRA method has high agreement regarding reliability compared with other quantitative measurements of root development after $\mathrm{RET}^{37}$. The present meta-analysis showed that $87.4 \%$ of the samples exhibited the increment of RRA, and this figure was found higher than the rate of root lengthening and thickening. Nevertheless, if a 20\% radiographic change was used as a cutoff point, only $34.9 \%$ of the samples showed an increment of RRA.

Nosrat et $\mathrm{al}^{38}$ published a case report showing root canal treatment performed on 2 teeth that received RET 6 years ago because of restorative and esthetic reasons. However, the canal of both teeth were found empty during the procedure with no vital tissue or bleeding identified even though there was radiographic evidence of apical closure ${ }^{38}$. It would be interesting to contemplate if the scaffold induced during RET survived in the first place. Previous histologic and radiographic studies showed the formation of a calcific barrier under a mineral trioxide aggregate barrier after vital pulp therapy39, 40, 41, 42, 43, 44, 45, 46. It was used as a sign of success of vital pulp therapy. Therefore, the same should be applied on RET; a calcific barrier or any form of calcification should be noted after RET to signify the presence of vital tissue in the canal. Total or partial pulpal obliteration was reported in a few studies ${ }^{12,15}, 16,17,20,21,47$. Despite being undesirable, total or partial pulpal obliteration were considered as favorable complications. Even though the presence of intracanal calcification was not the main finding or objective in this review, 7 studies mentioned that in their results. Therefore, this presentation was included in this meta-analysis because many were acknowledging its presence and significance in recent years $29,47,48,49$. Taking all types of calcification formed in the canal into account, this meta-analysis showed $28.4 \%$ of intracanal calcification after RET. This figure was much lower than a retrospective study by Song et al ${ }^{47}$ that exhibited $62.1 \%$ of RET-associated intracanal calcification. One possible explanation for the lower incidence of intracanal calcification found in this meta-analysis is that the periapical radiograph used in most of the included studies might not have the right resolution to display intracanal calcification. Further studies could consider the use of cone-beam computed tomographic imaging to identify if the resolution of the periapical radiograph is unable to display intracanal calcification.

In most of the RETs of necrotic immature permanent teeth, the etiology of pulpal necrosis was dental trauma, dental anomalies, or caries. With the limited data and studies included in the present study that differentiated the outcome of RET from different etiologies, we showed that clinically significant (>20\% positive value of radiographic changes) root lengthening and thickening were more predictable in dental anomalies compared with dental trauma (Table 5). According to Nagata et al ${ }^{31}$, dental trauma could disrupt the apical papilla cells, and the physical compression or stretch of Hertwig epithelial root sheath cells resulting from the trauma probably compromised the repair. Therefore, their study showed a lower increment of root length and thickness after RET on teeth with a history of trauma. However, further studies with a larger sample size and a longer follow-up are needed to draw a more 
conclusive relationship between the etiologies of necrotic immature permanent teeth and the root development outcome after RET.

Even though many articles on RET have been published, it is still difficult to make a direct comparison of their results or data on root development. This is because the case selection, clinical procedure, and case assessment for RET in those studies were widely varied. There is a need for clinicians and researchers to build a consensus to standardize all of these variables so a more compelling and meaningful conclusion can be made.

\section{Conclusions}

Within the limitations of the present review, it can be concluded that RET yielded high survival (97.3\%) and healing rates (93.0\%) with good root development $(77.3 \%$ root lengthening and $80.6 \%$ root thickening). However, clinical meaningful root development after RET remained unpredictable (16.1\% root lengthening and $39.8 \%$ root thickening).

\section{Acknowledgments}

The authors deny any conflicts of interest related to this study.

\section{Appendix 1Literature search strategies}

\section{PubMed/Medline}

("Regenerative Endodontics"[Mesh] OR “Regenerative endodontics" OR "regenerative endodontic" OR "Endodontic regeneration" OR ("Endodontics"[Mesh] AND "Regeneration"[Mesh] AND

"Therapeutics"[Mesh]) OR "regenerative endodontic therapy" OR "regenerative endodontic therapies" OR (Endodontolog* AND regenerat*) OR (endodontic* AND regenerat*) OR "Pulp Revascularization" OR "Pulp revitalization" OR ("Dental Pulp"[Mesh] AND revascular*) OR ("Dental Pulp"[Mesh] AND revitaliz*) OR ("Tissue Engineering"[Mesh] AND "Endodontics"[Mesh]) OR ("tissue engineering" AND endodontic*) OR "dental pulp stem cell” OR "dental pulp stem cells" OR "pulp regeneration" OR "Regeneration"[Mesh] OR Regenerat* OR Revascularization OR Revitalization OR "regenerative endodontic treatment" OR "regenerative endodontic procedures" OR "regenerative endodontic procedure" OR "regenerative treatment") AND (“Open apex" OR “open apices" OR "Dentition, Permanent"[Mesh] OR “permanent dentition" OR “secondary dentition" OR "adult dentition" OR "Permanent teeth" OR "permanent tooth" OR "Tooth"[Mesh] OR Tooth OR Teeth OR "Immature teeth" OR "immature permanent teeth" OR "immature tooth" OR "immature permanent tooth" OR "immature apex" OR "immature apices" OR "non-vital immature teeth" OR "non vital immature teeth" OR "nonvital immature teeth" OR "necrotic immature teeth" OR immature) AND ("Apical abscess" OR "Periapical Abscess"[Mesh] OR "periapical abscess" OR "Suppurative Periapical Periodontitis" OR "Periapical Abscesses" OR “Apical periodontitis" OR "Periapical Periodontitis"[Mesh] OR "Periapical Periodontitis" OR "Dental Pulp Necrosis"[Mesh] OR "dental pulp necrosis" OR “Pulp Necrosis" OR ("Dental Pulp"[Mesh] AND "Necrosis"[Mesh]) OR (“dental pulp" AND necrosis) OR ("dental pulps" AND necrosis) OR (“dental pulp" AND necroses) OR (“dental pulps" AND necroses) OR "pulp necrosis" OR "pulpal necrosis" OR "traumatized pulp" OR "Tooth, Nonvital"[Mesh] OR "Nonvital Tooth" OR "Devitalized Tooth" OR "Pulpless Tooth" OR "Pulpless Teeth" OR "Devitalized Teeth" OR "periapical lesion" OR "apical lesion" OR “apical radiolucency" OR "periapical radiolucency" OR "necrotic pulp" OR 
"chronic apical abscess" OR "chronic periapical abscess" OR "apical pathology" OR "infected pulp" OR "necrotic teeth" OR "necrotic tooth" OR "Nonvital Teeth" OR "Treatment Outcome"[Mesh] OR "treatment outcome" OR "non-vital tooth" OR "non-vital teeth")

Filters: Publication date from 1990/01/01 to 2019/12/31, English

\section{CINAHL (Cumulative Index to Nursing and Allied Health Literature)}

("Regenerative endodontic*" OR "Endodontic regeneration" OR ((MH "Endodontics+") AND (MH "Regeneration+") AND (MH "Therapeutics+") ) OR "regenerative endodontic therap*" OR (Endodontolog* AND regenerat*) OR (endodontic* AND regenerat*) OR "Pulp Revascularization" OR "Pulp revitalization" OR ((MH "Dental Pulp") AND (MH "Revascularization+")) OR (“Dental pulp*” AND revascular*) OR ((MH "Dental Pulp") AND revitaliz*) OR (“dental pulp*” AND revitaliz*) OR ((MH "Tissue Engineering") AND (MH "Endodontics+") ) OR ("tissue engineering" AND endodontic*) OR ("tissue generation" AND endodontic*) OR "dental pulp stem cell*" OR "pulp regenerat*" OR (MH "Regeneration+") OR Regenerat* OR (MH "Revascularization+") OR Revascularization OR Revitalization OR "regenerative endodontic treatment*" OR "regenerative endodontic procedure*" OR "regenerative treatment*") AND ("Open apex" OR "open apices" OR (MH "Dentition, Secondary") OR "permanent dentition" OR "secondary dentition" OR "secondary dentition" OR "adult dentition" OR "Permanent teeth" OR "permanent tooth" OR "Immature teeth" OR (MH "Tooth+") OR Tooth OR Teeth OR "Immature teeth" OR "immature permanent teeth" OR "immature tooth" OR "immature permanent tooth" OR “immature apex" OR "immature apices" OR "non-vital immature teeth" OR "non vital immature teeth" OR "nonvital immature teeth" OR "necrotic immature teeth" OR immature ) AND ( "Apical abscess*" OR "periapical abscess*" OR "Suppurative Periapical Periodontitis" OR "Apical periodontitis" OR "Periapical Periodontitis" OR ((MH "Dental Pulp") AND (MH "Necrosis+") ) OR (“dental pulp*" AND necrosis) OR ("dental pulp*" AND necroses) OR "pulp necrosis" OR "pulpal necrosis" OR "traumatized pulp" OR “Nonvital Tooth" OR “Devitalized Tooth" OR "Pulpless Tooth" OR "Pulpless Teeth" OR “Devitalized Teeth" OR "periapical lesion” OR “apical lesion” OR "apical radiolucency" OR "periapical radiolucency" OR "necrotic pulp" OR "chronic apical abscess" OR "chronic periapical abscess" OR "apical pathology" OR "infected pulp" OR "necrotic teeth" OR "necrotic tooth" OR “Nonvital Teeth" OR (MH "Treatment Outcomes+") OR "treatment outcome*" OR "Outcome* of Treatment*" OR “Treatment Effectiveness" OR "non-vital tooth" OR "non-vital teeth")

Limiters - English Language; Published Date: 19900101-20191231

\section{Cochrane (clinical trials)}

"Regenerative endodontic*" OR "Endodontic regenerat*" OR "regenerative endodontic therap*" OR (Endodontolog* AND regenerat*) OR (endodontic* AND regenerat*) OR "Pulp Revascularization" OR "Pulp revitalization" OR ("tissue engineering" AND endodontic*) OR "dental pulp stem cell*" OR "pulp regeneration" in Title Abstract Keyword AND "Open apex" OR "open apices" OR "permanent dentition" OR "secondary dentition" OR "adult dentition" OR "Permanent teeth" OR "permanent tooth" OR "Immature teeth" OR Tooth OR Teeth OR "immature permanent teeth" OR "immature tooth" OR "immature permanent tooth" OR "immature apex" OR "immature apices" OR "non-vital immature tooth" OR "non vital immature tooth" OR "nonvital immature tooth" OR "non-vital immature teeth" OR "non vital immature teeth" OR "nonvital immature teeth" OR "necrotic immature teeth" OR 
immature in Title Abstract Keyword AND "Apical abscess" OR "periapical abscess" OR "Suppurative Periapical Periodontitis" OR "Periapical Abscesses" OR “Apical periodontitis" OR "Periapical Periodontitis" OR “dental pulp necrosis" OR “Pulp Necrosis” OR (“dental pulp*” AND necrosis) OR ("dental pulp*" AND necroses) OR "pulp necrosis" OR "pulpal necrosis" OR "traumatized pulp" OR "Nonvital Tooth" OR “Devitalized Tooth" OR "Pulpless Tooth" OR "Pulpless Teeth" OR "Devitalized Teeth" OR "periapical lesion" OR "apical lesion" OR "apical radiolucency" OR "periapical radiolucency" OR "necrotic pulp" OR "chronic apical abscess" OR "chronic periapical abscess" OR "apical pathology" OR "infected pulp" OR "necrotic teeth" OR "necrotic tooth" OR "Nonvital Teeth" OR "treatment outcome*" OR "non-vital tooth" OR "nonvital tooth" OR "non vital tooth" OR "non-vital teeth" OR "non vital teeth" OR "nonvital teeth" in Title Abstract Keyword - (Word variations have been searched)

Web of Science

TOPIC: ("Regenerative endodontic*" OR “Endodontic regenerat*" OR "regenerative endodontic therap*" OR (Endodontolog* AND regenerat*) OR (endodontic* AND regenerat*) OR "Pulp Revascularization" OR "Pulp revitalization" OR ("tissue engineering" AND endodontic*) OR "dental pulp stem cell*" OR "pulp regeneration") AND TOPIC: (“Open apex" OR "open apices" OR "permanent dentition" OR "secondary dentition" OR "adult dentition" OR "Permanent teeth" OR "permanent tooth" OR "Immature teeth" OR Tooth OR Teeth OR "immature permanent teeth" OR "immature tooth" OR "immature permanent tooth" OR "immature apex" OR “immature apices" OR "non-vital immature tooth" OR "non vital immature tooth" OR "nonvital immature tooth" OR "non-vital immature teeth" OR "non vital immature teeth" OR "nonvital immature teeth" OR "necrotic immature teeth" OR immature) AND TOPIC: ("Apical abscess" OR "periapical abscess" OR "Suppurative Periapical Periodontitis" OR "Periapical Abscesses" OR “Apical periodontitis" OR "Periapical Periodontitis" OR "dental pulp necrosis" OR "Pulp Necrosis" OR ("dental pulp*" AND necrosis) OR ("dental pulp*" AND necroses) OR "pulp necrosis" OR "pulpal necrosis" OR "traumatized pulp" OR “Nonvital Tooth" OR "Devitalized Tooth" OR “Pulpless Tooth" OR "Pulpless Teeth" OR “Devitalized Teeth" OR "periapical lesion" OR "apical lesion" OR "apical radiolucency" OR "periapical radiolucency" OR "necrotic pulp" OR "chronic apical abscess" OR "chronic periapical abscess" OR "apical pathology" OR "infected pulp" OR "necrotic teeth" OR "necrotic tooth" OR "Nonvital Teeth" OR "treatment outcome*" OR "non-vital tooth" OR "nonvital tooth" OR "non vital tooth" OR “non-vital teeth" OR "non vital teeth" OR "nonvital teeth")

\section{References}

\section{J. Siqueira, I. Rôças, D. Ricucci, M. Hülsmann. Causes and management of post-treatment apical} periodontitis. Br Dent J, 216 (2014), pp. 305-312

2 I. Bender, S. Seltzer, W. Soltanoff. Endodontic success--a reappraisal of criteria. 1. Oral Surg Oral Med Oral Pathol, 22 (1966), pp. 780-789

$3 \mathrm{~L}$. Strindberg. The dependence of the results of pulp therapy on certain factors-an analytical study based on radiographic and clinical follow-up examination. Acta Odontol Scand, 14 (1956), pp. 1-175

4 M. Cvek, G. Tsilingaridis, J.O. Andreasen. Survival of 534 incisors after intra-alveolar root fracture in patients aged 7-17 years. Dent Traumatol, 24 (2008), pp. 379-387 
5 M. Torabinejad, A. Nosrat, P. Verma, O. Udochukwu. Regenerative endodontic treatment or mineral trioxide aggregate apical plug in teeth with necrotic pulps and open apices: a systematic review and meta-analysis. J Endod, 43 (2017), pp. 1806-1820

6 AAE clinical considerations for a regenerative procedure, American Association of Endodontists, Chicago, IL (2018), pp. 1-7

7 A.J. Smith, P.R. Cooper. Regenerative endodontics: burning questions. J Endod, 43 (2017), pp. S1-S6 8 A. Diogenes, M. Henry, F. Teixeira, K. Hargreaves. An update on clinical regenerative endodontics. Endod Topics, 28 (2013), pp. 2-23

9 G. Nicoloso, G. Goldenfum, T. Pizzol, et al. Pulp revascularization or apexification for the treatment of immature necrotic permanent teeth: systematic review and meta-analysis. J Clin Pediatr Dent, 43 (2019), pp. 305-313

$10 \mathrm{H}$. Tong, S. Rajan, N. Bhujel, et al. Regenerative endodontic therapy in the management of nonvital immature permanent teeth: a systematic review-outcome evaluation and meta-analysis. J Endod, 43 (2017), pp. 1453-1464

11 B. Kahler, S. Mistry, A. Moule, et al. Revascularization outcomes: a prospective analysis of 16 consecutive cases. J Endod, 40 (2014), pp. 333-338

12 T. Bezgin, A. Yilmaz, B. Celik, et al. Efficacy of platelet-rich plasma as a scaffold in regenerative endodontic treatment. J Endod, 41 (2015), pp. 36-44

13 E. Chan, M. Desmeules, M. Cielecki, et al. Longitudinal cohort study of regenerative endodontic treatment for immature necrotic permanent teeth. J Endod, 43 (2017), pp. 395-400

$14 \mathrm{~L}$. Li, Y. Pan, L. Mei, J. Li. Clinical and radiographic outcomes in immature permanent necrotic evaginated teeth treated with regenerative endodontic procedures. J Endod, 43 (2017), pp. 246-251

$15 \mathrm{~J}$. Lin, Q. Zeng, X. Wei, et al. Regenerative endodontics versus apexification in immature permanent teeth with apical periodontitis: a prospective randomized controlled study. $J$ Endod, 43 (2017), pp. 1821-1827

16 C. Peng, Y. Yang, Y. Zhao, et al. Long-term treatment outcomes in immature permanent teeth by revascularisation using MTA and GIC as canal-sealing materials: a retrospective study. Int J Paediatr Dent, 27 (2017), pp. 454-462

$17 \mathrm{~J}$. Silujjai, P. Linsuwanont. Treatment outcomes of apexification or revascularization in nonvital immature permanent teeth: a retrospective study. J Endod, 43 (2017), pp. 238-245

$18 \mathrm{H}$. Nazzal, K. Kenny, A. Altimimi, et al. A prospective clinical study of regenerative endodontic treatment of traumatized immature teeth with necrotic pulps using bi-antibiotic paste. Int Endod J, 51 (2018), pp. 1946-1952

19 M. EzEldeen, G. Van Gorp, J. Van Dessel, et al. 3-dimensional analysis of regenerative endodontic treatment outcome. J Endod, 41 (2015), pp. 317-324

20 V. Shivashankar, D. Johns, R. Maroli, et al. Comparison of the effect of PRP, PRF and induced bleeding in the revascularization of teeth with necrotic pulp and open apex: a triple blind randomized clinical trial. J Clin Diagn Res, 11 (2017), pp. ZC34-ZC39

21 T. Saoud, A. Zaazou, A. Nabil, et al. Clinical and radiographic outcomes of traumatized immature permanent necrotic teeth after revascularization/revitalization therapy. J Endod, 40 (2014), pp. 1946-1952 
22 S. Bukhari, M. Kohli, F. Setzer, B. Karabucak. Outcome of revascularization procedure: a retrospective case series. J Endod, 42 (2016), pp. 1752-1759

23 A. Alagl, S. Bedi, K. Hassan, J. AlHumaid. Use of platelet-rich plasma for regeneration in non-vital immature permanent teeth: clinical and cone-beam computed tomography evaluation. J Int Med Res, 45 (2017), pp. 583-593

24 S. Shabahang. Treatment options: apexogenesis and apexification. Pediatr Dent, 35 (2013), pp. $125-128$

$25 \mathrm{E}$. Sheehy, G. Roberts. Use of calcium hydroxide for apical barrier formation and healing in nonvital immature permanent teeth: a review. Br Dent J, 183 (1997), pp. 241-246

26 T. Jeeruphan, J. Jantarat, K. Yanpiset, et al. Mahidol study 1: comparison of radiographic and survival outcomes of immature teeth treated with either regenerative endodontic or apexification methods: a retrospective study. J Endod, 38 (2012), pp. 1330-1336

27 F. Masmoudi, I. Bourmeche, A. Sebai, et al. Root lengthening with apical closure in two maxillary immature permanent central incisors after placement of mineral trioxide aggregate (MTA) as an apical plug. Eur Arch Pediatr Dent, 19 (2018), pp. 65-71

$28 \mathrm{~J}$. Tenca, A. Tsamtsouris. Continued root end development: apexogenesis and apexification. $J$ Pedod, 2 (1978), pp. 144-157

29 L. Lin, S. Kim, G. Martin, B. Kahler. Continued root maturation despite persistent apical periodontitis of immature permanent teeth after failed regenerative endodontic therapy. Aust Endod J, 44 (2018), pp. 292-299

30 G. Jadhav, N. Shah, A. Logani. Revascularization with and without platelet-rich plasma in nonvital, immature, anterior teeth: a pilot clinical study. J Endod, 38 (2012), pp. 1581-1587

$31 \mathrm{~J}$. Nagata, B. Gomes, T. Rocha Lima, et al. Traumatized immature teeth treated with 2 protocols of pulp revascularization. J Endod, 40 (2014), pp. 606-612

32 M. Nagy, H. Tawfik, A. Hashem, A. Abu-Seida. Regenerative potential of immature permanent teeth with necrotic pulps after different regenerative protocols. J Endod, 40 (2014), pp. 192198

33 I. Narang, N. Mittal, N. Mishra. A comparative evaluation of the blood clot, platelet-rich plasma, and platelet-rich fibrin in regeneration of necrotic immature permanent teeth: a clinical study. Contemp Clin Dent, 6 (2015), pp. 63-68

34 A. Alobaid, L. Cortes, J. Lo, et al. Radiographic and clinical outcomes of the treatment of immature permanent teeth by revascularization or apexification: a pilot retrospective cohort study. $J$ Endod, 40 (2014), pp. 1063-1070

35 B. Estefan, K. El Batouty, M. Nagy, A. Diogenes. Influence of age and apical diameter on the success of endodontic regeneration procedures. J Endod, 42 (2016), pp. 1620-1625

36 N. Flake, J. Gibbs, A. Diogenes, et al. A standardized novel method to measure radiographic root changes after endodontic therapy in immature teeth. J Endod, 40 (2014), pp. 46-50

37 N. Sutam, J. Jantarat, L. Ongchavalit, et al. A comparison of 3 quantitative radiographic measurement methods for root development measurement in regenerative endodontic procedures. J Endod, 44 (2018), pp. 1665-1670

38 A. Nosrat, N. Homayounfar, K. Oloomi. Drawbacks and unfavorable outcomes of regenerative endodontic treatments of necrotic immature teeth: a literature review and report of a case. $J$ Endod, 38 (2012), pp. 1428-1434 
39 A. Eskandarizadeh, M. Shahpasandzadeh, M. Shahpasandzadeh, et al. A comparative study on dental pulp response to calcium hydroxide, white and grey mineral trioxide aggregate as pulp capping agents. J Conserv Dent, 14 (2011), pp. 251-255

40 Z. Li, L. Cao, M. Fan, Q. Xu. Direct pulp capping with calcium hydroxide or mineral trioxide aggregate: a meta-analysis. J Endod, 41 (2015), pp. 1412-1417

41 A. Nosrat, A. Peimani, S. Asgary. A preliminary report on histological outcome of pulpotomy with endodontic biomaterials vs calcium hydroxide. Restor Dent Endod, 38 (2013), pp. 227-233

$42 \mathrm{M}$. Caliskan. Clinical reliability of the dentine bridge formed after pulpotomy: a case report. Int Endod J, 27 (1994), pp. 52-55

43 K. Barrieshi-Nusair, M. Qudeimat. A prospective clinical study of mineral trioxide aggregate for partial pulpotomy in cariously exposed permanent teeth. J Endod, 32 (2006), pp. 731-735

$44 \mathrm{M}$. Eghbal, S. Asgary, R. Baglue, et al. MTA pulpotomy of human permanent molars with irreversible pulpitis. Aust Endod J, 35 (2009), pp. 4-8

45 M. Qudeimat, A. Alyahya, A. Hasan. Mineral trioxide aggregate pulpotomy for permanent molars with clinical signs indicative of irreversible pulpitis: a preliminary study. Int Endod J, 50 (2017), pp. 126-134

46 L. Chueh, C. Chiang. Histology of irreversible pulpitis premolars treated with mineral trioxide aggregate pulpotomy. J Endod, 35 (2010), pp. 370-374

47 M. Song, Y. Cao, S. Shin, et al. Revascularization-associated intracanal calcification: assessment of prevalence and contributing factors. J Endod, 43 (2017), pp. 2025-2033

48 B. Kahler, S.L. Kahler, L. Lin. Revascularization-associated intracanal calcification: a case report with an 8-year review. J Endod, 44 (2018), pp. 1792-1795

$49 \mathrm{M}$. Chen, K. Chen, C. Chen, et al. Responses of immature permanent teeth with infected necrotic pulp tissue and apical periodontitis/abscess to revascularization procedures. Int Endod J, 45 (2012), pp. 294-305 